\title{
The liverworts of the Khulga River Basin (Subpolar Urals, Khanty-Mansi Autonomous Area - Yugra)
}

\author{
Nadezhda A. Konstantinova ${ }^{1}$, Elena D. Lapshina ${ }^{2}$, Ilya V. Filippov \\ ${ }^{1}$ Polar-Alpine Botanical Garden-Institute of the Kola Science Center of RAS, 184256 Kirovsk, Murmansk Province, Russia. \\ E-mail: nadya50@list.ru \\ ${ }^{2}$ Yugra State University, 16 Chekhov St., 628012 Khanty-Mansiysk, Russia. E-mail: e_lapshina@ugrasu.ru
}

\begin{abstract}
The annotated list of liverworts of Khulga River Basin (Subpolar Urals, north-east part of Khanty-Mansi Autonomous Area - Yugra) is compiled based on identification of 300 specimens gathered by E. D. Lapshina and I. V. Filippov in 2018. It counts 84 species, among them two species new for the Urals and five species (Arnellia fennica, Frullania austinii, Mesoptychia rutheana, Metzgeria furcata, Scapania sphaerifera) new for Subpolar Urals. Annotations to the species include distribution, description of habitats and data on reproduction structures. Comparison with two previously studied local floras as well as the full list of liverworts of Asian part of the Urals is provided. A total of 144 species have now been recorded in three studies of the Urals territories within the Khanty-Mansi Autonomous Area.
\end{abstract}

Keywords: liverworts, ecology, distribution, phytogeography, flora, Subpolar Urals, Russia

\section{INTRODUCTION}

The liverworts of the Urals are still a relatively poorly studied. Most of the studies covered mainly the Western slopes of the Northern and Middle Urals (Zinovjeva, 1973; Baisheva \& Potemkin, 1998; Bakalin et al., 2001; Dulin, 2007; Konstantinova et al., 2010; Konstantinova \& Bezgodov, 2005; Ignatova et al., 2019;). Information about the liverworts of the Polar and Subpolar Urals is extremely limited. There is only one publication on the Sob' river valley in the Polar Urals (Konstantinova \& Chernyadjeva, 1995). Data on liverworts of the Eastern slopes of the Urals are presented in two more or less comprehensive lists of species of the Subpolar Urals: the Ner-Oika Mountain and the basin of Puiva river (Konstantinova \& Lapshina, 2014, 2017). This paper provides the results of identifications of specimens collected in the basin of the Khulga River, located in the North-Eastern part of the Subpolar Urals, about $120 \mathrm{~km}$ from the previously studied sites.

\section{STUDY AREA}

The study area is located in the Beresovskiy District in north-west part of the Khanty-Mansi Autonomous Area (Yugra).The sources of the Khulga River are located slightly south of the Arctic circle on the border of the Polar and Subpolar Urals. The river flows along the eastern slope of the Ural Mountains to the South to the
Severnaya Sosva River which is a left tributary of the Ob River. In the middle and lower reaches, the river flows through a flat, sometimes gently undulating plain with absolute elevations of 40-90 $\mathrm{m}$ above sea level The narrow regularly flooded part of river valley is occupied by welldrained forests and wet lowlands. Flat river valley terraces are poorly drained and covered with raised and transitional peat bogs and swampy open woodlands with Pinus sibirica Du Tour and Picea obovata Ledeb. Local permafrost is widespread in the peatlands and thermokarst landforms are widely represented

On the right bank in the upper reaches of the river, up to a height of 350-400 m alt. mountain birch-spruce-larch forests and their derivatives predominate. In the subalpine zone, up to a height of 450-500 m, Pinus sibirica-Betula pubescens Ehrh. with an admixture of Larix sibirica Ledeb. open forests, alternating with thickets of Betula nana L. and Duschekia fruticosa Opiz are widespread. The mountain tundra is represented on the highest peaks, reaching a height of 600-750 m.

Mountains are composed of metamorphic and intrusive rocks, with frequent outcrops of carbonates. This provides a diversity of rocks from pure carbonates to rocks of basic, neutral and acidic compositions. For a more detailed descrip- 
tion of the vegetation and habitats see Lapshina et al. (2020).

\section{MATERIAL AND METHODS}

Liverworts were gathered in the basin of the Khulga River from 7 to 18 July 2018 by Elena Lapshina and Ilya Filippov. The routes were planned to cover all the diversity of the main vegetation types. Landsat 8 satellite images with a resolution of $15 \mathrm{~m}$ were used for this purpose. The valleys of small rivers and streams, rock outcrops, banks of rivers and lakes were studied most thoroughly. In total 300 specimens were collected from 190 sites at altitudes from 24 to $625 \mathrm{~m}$. On the map all collecting sites are grouped into 24 locations within four key territories (Fig. 1). For all collecting sites the coordinates and elevations were measured using GPS. The collected specimens were studied in the laboratory of the Polar-Alpine Botanical Garden-Institute (Kirovsk, Murmansk Province). The specimens are deposited in the Biological collection of Yugra State University (YSU); some duplicates are deposited in the Herbarium of Polar-Alpine Botanical Garden-Institute of the Kola Scientific Center, Russian Academy of Sciences (KPABG). Label data of duplicates are incorporated in the CRIS - Cryptogamic Russian Information System (kpabg.ru/cris/?q=node/16).

\section{Collecting localities (Fig.1.)}

I. Upper Khulga River near the mouth of Tykotlova River (right tributary of Khulga River).

Valley of Khulga River: 1 - right bank, $2 \mathrm{~km}$ below mouth of Tykotlova River, $65.252^{\circ} \mathrm{N}$, $62.170^{\circ}-62.177^{\circ} \mathrm{E}, 61 \mathrm{~m}$ alt.; 2 - near the mouth of Tykotlova River, $65.253^{\circ}-65.269^{\circ} \mathrm{N}, 62.177^{\circ}-$ $62.184^{\circ} \mathrm{E}, 61 \mathrm{~m}$ alt.; 3 - left bank, $2 \mathrm{~km}$ above mouth of Tykotlova River, $65.278^{\circ}-65.286^{\circ} \mathrm{N}$, $62.189^{\circ}-62.207^{\circ} \mathrm{E}, 66 \mathrm{~m}$ alt.

Tykotlova peatland area between the valleys of the Khulga and Tykotlova Rivers: 4 - flat palsa bog, $65.275^{\circ}-65.285^{\circ} \mathrm{N}, 62.132^{\circ}-62.147^{\circ} \mathrm{E}$, $66 \mathrm{~m}$ alt.; 5 - rich fen in area of carbonate groundwater discharge, $65.253^{\circ}-65.269^{\circ} \mathrm{N}$, $62.177^{\circ}-62.184^{\circ} \mathrm{E}, 68 \mathrm{~m}$ alt.; 6 - sloping bog at base of carbonate rock outcrops, $65.297^{\circ} \mathrm{N}$, $62.128^{\circ} \mathrm{E}, 72 \mathrm{~m}$ alt.

Mid-mountain belt eastern ridges of Subpolar Urals: 7 - shore of lake in intermontane basin, $65.302^{\circ} \mathrm{N}, 62.075^{\circ} \mathrm{E}, 75 \mathrm{~m}$ alt.; 8 - rich fen at base of carbonate rock by lake, $65.298^{\circ} \mathrm{N}$, $62.095^{\circ} \mathrm{E}, 75 \mathrm{~m}$ alt.; 9 - carbonate rocks and carbonate outcrops in spruce-larch forest, $65.301^{\circ} \mathrm{N}, 62.119^{\circ} \mathrm{E}, 105 \mathrm{~m}$ alt.; 10 - dry carbonate rocks on steep slope of southern exposure, $65.298^{\circ} \mathrm{N}, 62.085^{\circ} \mathrm{E}, 81 \mathrm{~m}$ alt.; 11 - huge boulder on gentle north-eastern faced slope, $65.277^{\circ} \mathrm{N}, 62.111^{\circ} \mathrm{E}, 92 \mathrm{~m}$ alt,; 12 - valley in the middle reaches of Tykotlova River, $65.278^{\circ} \mathrm{N}$, $62.101^{\circ} \mathrm{E}, 72 \mathrm{~m}$ alt.

II. Upper reaches of the Khulga River in the area of the Balbanty Lake. 13 - valley of Khulga River, $2 \mathrm{~km}$ east of the Balbanty Lake, $65.150^{\circ}-$ $65.154^{\circ} \mathrm{N}, 62.108^{\circ}-62.126^{\circ} \mathrm{E}, 52 \mathrm{~m}$ alt. The eastern spurs of the Subpolar Urals: 14 - lower part of western slope and swampy valley of Balbanshor Brook on northern shores of lake in forest belt, $65.161^{\circ}-65.176^{\circ} \mathrm{N}, 62.026^{\circ}-62.048^{\circ} \mathrm{E}$, $81 \mathrm{~m}$ alt.; 15 - deep intermontane brook valley near the timberline, $65.201^{\circ} \mathrm{N}, 61.996^{\circ} \mathrm{E}, 487$ $\mathrm{m}$ alt.; 16 - gentle slopes and plateaus at the top of mountain tundra belt, $65.202^{\circ}-65.210^{\circ} \mathrm{N}$, $61.970^{\circ}-61.986^{\circ} \mathrm{E}, 510 \mathrm{~m}$ alt.; 17 - upper Balbanshor Brook under snowfield, $65.216^{\circ}-$ $65.222^{\circ} \mathrm{N}, 61.922^{\circ}-61.939^{\circ} \mathrm{E}, 608 \mathrm{~m}$ alt.;18 - valley of the Khulga River, near the mouth of Balban'yu River, $65.104^{\circ} \mathrm{N}, 62.216^{\circ}-62.218^{\circ} \mathrm{E}$, $46 \mathrm{~m}$ alt.

III. Valley of the Khulga River in its middle course: 19 - high palsa-hollow complex on right bank of Khulga River, $64.936^{\circ}-64.937^{\circ} \mathrm{N}$, $61.993^{\circ}-61.999^{\circ} \mathrm{E}, 45 \mathrm{~m}$ alt.; 20 - coastal siltysand sediment outcrop along on left bank of river, $64.870^{\circ} \mathrm{N}, 62.034^{\circ} \mathrm{E}, 40 \mathrm{~m}$ alt.; $21-$ mesooligotrophic aapa mire complex with palsas on left-bank terrace of the Khulga River, $64.870^{\circ}-$ $64.871^{\circ} \mathrm{N}, 62.042^{\circ}-62.046^{\circ} \mathrm{E}, 43 \mathrm{~m}$ alt.; $22-$ left bank of the Khulga River opposite the mouth of Khalmer'yu River, $64.558^{\circ} \mathrm{N}, 61.642^{\circ} \mathrm{E}, 43 \mathrm{~m}$ alt.

IV. Valley of the Khulga River at its lower reaches. Left-bank terrace near the mouth of Man'ya River (right tributary of the Khulga River): 23 aapa mire complex, $64.348^{\circ}-64.349^{\circ} \mathrm{N}, 61.107^{\circ}$ $-61.150^{\circ} \mathrm{E}, 25 \mathrm{~m}$ alt.; $24-$ mesotrophic poor fen, $64.337^{\circ}-64.339^{\circ} \mathrm{N}, 61.066^{\circ}-61.067^{\circ} \mathrm{E}, 24 \mathrm{~m}$ alt.

\section{ANNOTED LIST OF SPECIES}

The annotated list of liverworts includes 84 species. The nomenclature of bryophytes generally follows Hodgetts et al. (2020). The species in the list are arranged in alphabetical order. Common synonyms are given in square brackets. After 


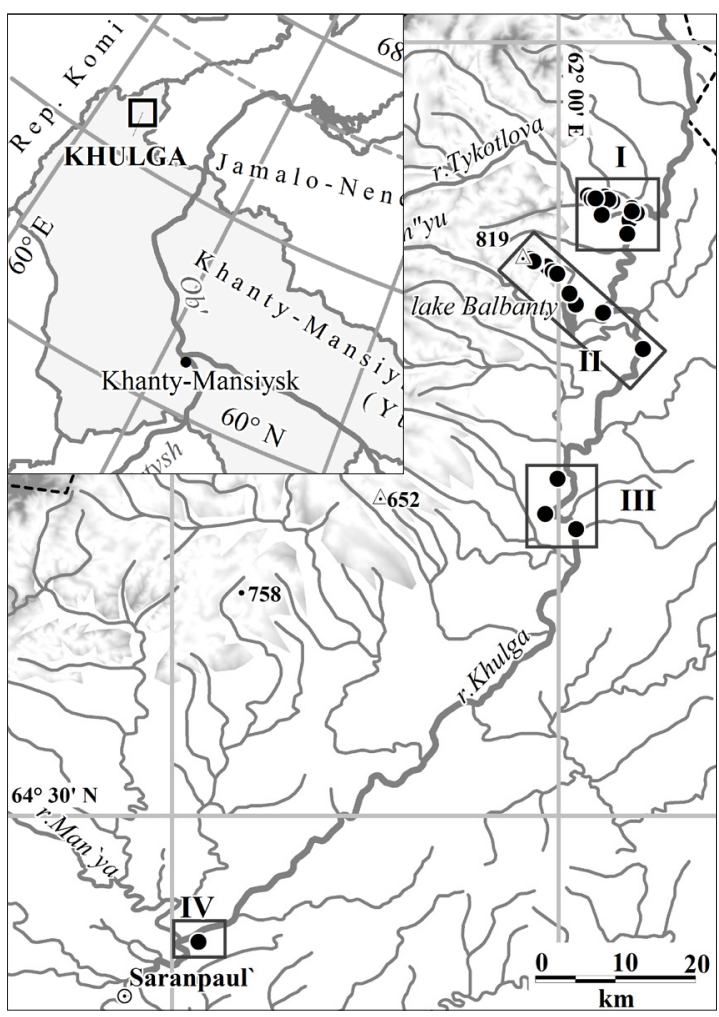

Fig. 1. Collecting localities.

the species name the presence of reproductive structures is given in parentheses (and. - androecia; gyn. - gynoecia; per. - perianths or pseudoperianths; spor. - sporophytes; gem. - gemmae). Habitat characteristics and some accompanying species are given for sporadic and widespread species, and at least one reference to a herbarium number in the Cryptogamic Russian Information System - CRIS (kpabg.ruıcris / ?q=node / 16) or the Biological collection of Yugra State University (YSU) is cited. For species collected from 1-2 (3) localities, labels are given in full and the herbarium numbers of specimens in the Herbarium of Polar-Alpine Botanical Garden-Institute (KPABG) or Biological collection of Yugra State University (YSU) are specified. The frequency is characterized as: sporadic (Sp., 3-6 localities), frequent (Fr., 7-13 localities) and common (Com., more than 13 localities). New records for the Khanty-Mansiysk Autonomous Area - Yugra are marked as one asterisk $\left.{ }^{*}\right)$, new records for the Subpolar Urals - as two asterisks $\left({ }^{* *}\right)$, and new records for the Urals as three asterisks $\left(^{* * *}\right)$.
Aneura Pinguis (L.) Dumort. - 5, 17, 21: on bare peat in poor fens or scattered in mats of Sphagnum warnstorfii, Ptychostomum pseudotriquetrum in rich fens and dwarf shrubs (Betula nana, Salix)-sedge (Carex arctisibirica)-Sphagnum warnstorfii mires in forest and tundra zone [YSU-MH-00521].

Anthelia JuRATZKana (Limpr.) Trevis. (per., spor.) - 16, 17: on clay spots in rocky dwarf shrub tundra on top of mountain, [YSU-MH-00503], on stream banks under snowfield, on moist organic-mineral substrate. Often mixed with other arctomontane liverworts (Marsupella sprucei, Prasanthus suecicus, Barbilophozia sudetica etc.) or liverworts widespread in the north of holarctic (Blepharostoma trichophyllum, Fuscocephaloziopsis pleniceps, Mesoptychia heterocolpos, etc) [KPABG(H):22287].

** ARnEllia FEnNica (Gottsche) Lindb. - 9: carbonate boulders in coniferous (Picea obovata, Larix sibirica, Pinus sibirica) dwarf shrub-green-moss forest, between rocks, mixed with Tritomaria scitula, Mesoptychia heterocolpos [YSU-MH-00148]; 10: rock outcrop, in moist shaded niches, in pure mats and mixed with Myurella tenerrima, Pohlia cruda, Bryoerythrophyllum recurvirostrum, Scapania gymnostomophila, Cyrtomnium hymenophylloides, Platydictya jungermannioides [KPABG(H):122255]; 11: huge boulder, in shaded niches, single shoots in turf of Scapania gymnostomophila [YSU-MH-00344]. Previously the species was only known on the European slopes of the Urals. It is reported for the first time for the Asian part of the Urals.

BARBILOPHOZIA BARBATA (Schmidel ex Schreb.) Loeske-1, 3, 7, 9, 11, 15 (Fr.): in dark coniferous and mixed (Picea obovata, Pinus sibirica, Betula pubescens, Larix sibirica) shrub-herb and grassgreen-moss short-flooded river valley forests, in the forest floor, in pure mats [KPABG(H):122250] or mixed with Sciuro-hypnum curtum, Eurhynchiastrum pulchellum, Pleurozium schreberi, Abietinella abietina, Hypnum cupressiforme and Lophocolea minor.

BARBILOPHOZIA HATCHERI (A. Evans) Loeske - 15: rock outcrops on steep slopes, on cliff ledges on forest litter [YSU-MH-00418], in pure mats or mixed with Lescuraea saxicola [YSU-MH-00417].

BARBILOPHOZIA SUdETICA (Nees ex Huebener) L.Söderstr., De Roo \& Hedd. [Lophozia sudetica (Nees ex Huebener) Grolle, Pseudolophozia su- 
detica (Nees ex Huebener) Konstant. \& Vilnet] (gem.) - 16 (Sp.): in rocky dwarf shrub tundra, between rocks, on fine earth, mixed with $D i$ plophyllum taxifolium and Lophozia murmanica [KPABG(H):122273]; in Betula nana dominated tundra on clay spots, single shoots among Prasanthus suecicus, Gymnomitrion concinnatum, $G$. corallioides, Solenostoma sp., Sphenolobus minutus, Isopaches bicrenatus and Scapania parvifolia [YSU-MH-00504]; 17: on bank of stream under snowfield, on fine earth mixed with Mesoptychia heterocolpos, Anthelia juratzkana, Blepharostoma trichophyllum, Schljakovianthus quadrilobus and Fuscocephaloziopsis pleniceps [YSU-MH-00535].

BLASIA PUSILLA L. (gem.) - 20: on river-bank on silty sandy soil [KPABG(H):122292].

Blepharostoma trichophyllum (L.) Dumort. - 3, $11,14,15,17$ (Fr.): on soil in moist river valley forests, on rock outcrops covered by fine earth, between rocks in mountain forests and dwarf shrub tundras, on banks of streams under snowfield in pure mats [KPABG(H):122263] or mixed with other bryophytes.

Calypogeia neesiana (C. Massal. et Carestia) Müll. Frib. (spor.) - 6, 13, 14 (Sp.): on decaying wood, in boggy shrub-peat-moss (Sphagnum fuscum, S. girgensohnii) open spruce and Pinus sibiricaspruce woodlands, [YSU-MH-00096], on peat in hollows between roots in moist Calamagrostisherb-birch forests [KPABG(H): 122264], in pure mats or mixed with other bryophytes.

Calypogeia sphagnicola (Arnell et J.Perss.) Warnst. et Loeske - 6: Betula nana-Rubus chamaemorus-Sphagnum fuscum spruce open woodland, on peat [KPABG(H):122247] and in Sphagnum turfs, always as single shoots with Cephalozia leucantha, Mylia anomala etc. [YSU-MH-00103]; 13: boggy shrub-Sphagnum girgensohnii-Pinus sibirica-spruce open woodland, on decayed wood, single shoots in Lophozia silvicola mats [YSU-MH-00365].

Cephalozia ambigua C. Massal. - 6: spruce Betula nana-Rubus chamaemorus-Sphagnum fuscum open woodland, on peat, mixed with Cephalozia leucantha, Protolophozia elongata, Calypogeia sphagnicola, C. neesiana, Sphenolobus minutus [KPABG(H): 122247].

Cephalozia bicuspidata (L.) Dumort. (per.) - 3, 13, 16, 17 (Sp.): on soil and decaying wood in birch-spruce shrub-herb floodplain forests
[YSU-MH-00198], in boggy peat-moss woodlands, on stream banks under snowfields [KPABG(H): 122287], on clay spots in dwarf birch tundra, usually mixed with other bryophytes, more often with Anthelia juratzkana, Blepharostoma trichophyllum, Trilophozia quinquedentata.

Cephaloziella cf. Hampeana (Nees) Schiffn. - 1: birch-willow sedge-Sphagnum bog [YSUMH-00231], single shoots among Scapania paludicola and Ptychostomum pseudotriquetrum.

Cephaloziella spinigera (Lindb.) Warnst. - 21: on edge of cotton grass-peat-moss (Sphagnum balticum) hollow at base of flat palsa [KPABG(H):122293], single shoots mixed with Mylia anomala.

Diplophyllum taXifolium (Wahlenb.) Dumort. 15, 16, 17 (Sp.): on cliffs in forest zone, between rocks, in rocky dwarf shrub tundra in pure mats [YSU-MH-00501] or mixed with Barbilophozia sudetica, Lophozia murmanica, Gymnomitrion concinnatum, Gymnocolea inflata and Tetralophozia setiformis [KPABG(H):122273].

*** Frullania AUSTINII J. J. Atwood, Vilnet, Mamontov et Konstant. - 15: rock outcrops on mountainside in young birch forest, single shoots in turf of Grimmia longirostris [KPABG(H):122267] and among Zygodon sibiricus [YSU-MH-00433]; 16: large boulder in dwarf birch tundra, on rock in turf of Orthotrichum sp. [KPABG(H):122274]. This is a recently described species (Mamontov et al., 2020) previously referred to $F$. bolanderi.

FuscocephalOziopsis ALBEscens (Hook.) Váňa et L. Söderstr. [Pleurocladula albescens (Hook.) Grolle] - 17: bank of stream under snowfield, on fine earth, mixed with Lophozia murmanica, Diplophyllum taxifolium, Pohlia drummondii. [KPABG(H):122283]

FuscocePhaloziopsis ConNivens (Dicks.) Váňa et L. Söderstr. [Cephalozia connivens (Dicks.) Lindb.] - 6: boggy Betula nana-Rubus chamaemorusSphagnum fuscum open spruce woodland at the base of carbonate outcrops [YSU-MH-00103], mixed with Mylia anomala.

Fuscocephaloziopsis LEUCANTHA (Spruce) Váňa et L. Söderstr. [Cephalozia leucantha Spruce] - 6: boggy Betula nana-Rubus chamaemorusSphagnum fuscum open spruce woodland at the base of carbonate outcrops, on peat, mixed with Protolophozia elongata, Cephalozia ambigua, Calypogeia spp. and Sphenolobus minutus 
[KPABG(H):122247]. It is the second record for Khanty-Mansi Autonomous Area, until now the species was only found in the Nature Park "Numto" (Lapshina et al., 2018).

Fuscocephaloziopsis lunulifolia (Dumort.) Váňa et L. Söderstr. [Cephalozia lunulifolia (Dumort.) Dumort.] (per, spor.) - 3, 6, 14 (Sp.): in birch and moist mixed forests, boggy Betula nanaRubus chamaemorus-Sphagnum fuscum open spruce woodland, on decayed wood in pure mats [KPABG $(\mathrm{H}): 122262]$ or mixed with Lophocolea heterophylla, Lophozia guttulata, L. ascendens, Lophoziopsis longidens, Tritomaria exsectiformis, Riccardia latifrons and Scapania curta.

Fuscocephaloziopsis Pleniceps (Austin) Váňa et L. Söderstr. [Cephalozia pleniceps (Austin) Lindb.] (per., ant.) - 3, 6, 13, 14, 17 (Sp.): on soil in floodplain forests and boggy dwarf birchpeat-moss Pinus sibirica-spruce woodlands in mats with Schistochilopsis grandiretis, Rhizomnium pseudopunctatum [KPABG(H):122261], on banks of streams in the mountain-tundra, with Barbilophozia sudetica, Blepharostoma trichophyllum, Mesoptychia heterocolpos, M. collaris, Anthelia juratzkana and Schljakovianthus quadrilobus.

Gymnocolea inflata (Huds.) Dumort. - 16: dwarf shrub (Betula nana, Vaccinium uliginosum, Empetrum hermaphroditum) tundra, on fine earth mixed with Diplophyllum taxifolium, Lophozia murmanica and Gymnomitrion concinnatum [YSU-MH-00493].

Gymnomitrion concinnatum (Lightf.) Corda - 16: rocky dwarf shrub tundra, between stones on fine earth, in pure mats [KPABG(H):122272] and mixed with Lophozia wenzelii, L. murmanica, Diplophyllum taxifolium and Sphenolobus minutus; and dwarf birch tundra on clay spots, mixed with Gymnomitrion corallioides, etc. (see below). [YSU-MH-00504].

GYMNOMITRION CORALLIOIDES Nees - 16: dwarf birch tundra, on clay spots, some shoots mixed with Gymnomitrion concinnatum, Prasanthus suecicus, Solenostoma sp., Sphenolobus minutus, Barbilophozia sudetica, Isopaches bicrenatus and Scapania parvifolia [YSU-MH-00504].

Heterogemma LaXa (Lindb.) Konstant. et Vilnet 6, 14, 21 (Sp.): sides of Sphagnum hummocks, often on dried Sphagnum in boggy Betula nanaSphagnum fuscum open Pinus sibirica-Picea obovata woodlands, on side of hummock in aapa mire, sedge-Menyanthes hollow. Always scattered in mats or turfs of bryophytes, more often among Sphagnum fuscum, Tomentypnum nitens and Rhizomnium pseudopunctatum [YSU$\mathrm{MH}-00048]$;

ISOPACHES BICRENATUS (Schmidel ex Hoffm.) H.Buch - 16: dwarf birch tundra on bare clay spots, single shoots among Gymnomitrion corallioides, G. concinnatum, Prasanthus suecicus, Solenostoma sp., Sphenolobus minutus, Barbilophozia sudetica and Scapania parvifolia [YSU-MH-00504].

JUNGERMANNIA PUMILA With. (per., ant., spor) - 17 in pure mat on rocks in stream bed under snowfield [KPABG(H):122277] and on fine earth on stream bank mixed with Marchantia quadrata, Solenostoma confertissimum, Trilophozia quinquedentata, Mesoptychia heterocolpos, Philonotis tomentella and Bartramia ithyphylla.

LEPIDOZIA REPTANS (L.) Dumort. - 1: larch-birchspruce shrub-green moss old-growth forest in river valley, on decayed wood in pure mats [KPABG(H):122251]; 23: aapa mire, dwarf shrub-Sphagnum divinum ridge with stunted Pinus silvestris, at the base of pine trunk, mixed with Pohlia nutans and Schljakovia kunzeana [YSU-MH-00798].

Lophocolea heterophylla (Schrad.) Dumort. (per.) - 3, 14 (Sp.): birch and birch-spruce with herb- shrub layer floodplain forests, on decayed wood, in pure mats and mixed with Fuscocephaloziopsis lunulifolia, Lophozia ascendens, L. guttulata and Lophocolea minor [KPABG(H):122243].

LOPHOCOlEa Minor Nees (gem.) -1, 3, 7 (Sp.): on soil in birch-spruce and mixed (Picea obovata, Betula pubescens, Pinus sibirica, Larix sibirica) shrub-herb-green moss forests in river valley, on dry peat ledge along lake shore [KPABG(H):122294].

Lophozia ascendens (Warnst.) R. M. Schust. (gem.) - 1: birch-spruce river valley forest, on decaying wood numerous in mats with dominance of Lophozia guttulata; [KPABG(H):122244]; 3: birch-spruce river valley forest, on decayed wood in mats with dominance of Lophocolea heterophylla [KPABG(H):122294].

Lophozia GutTulata (Lindb. et Arnell) A. Evans (gem., ant., per.) - 1: birch-spruce river valley 
forest, on decayed wood, mixed with Lophoziopsis longidens, Tritomaria exsectiformis, Scapania curta, Lophozia ascendens, Fuscocephaloziopsis lunulifolia, Lophocolea heterophylla and Cephalozia bicuspidata [KPABG(H):122244]; 3: birchspruce river valley forest, on decayed wood, mixed with Lophozia ascendens, Lophocolea heterophylla and L. minor [KPABG(H):122294].

LOPHOZIA LONGIFLORA (Nees) Schiffn. [Lophozia ventricosa var. longiflora (Nees) Macoun] - 6: boggy Betula nana-Rubus chamaemorus- Sphagnum fuscum open spruce woodland at the base of mountain slope, mixed with Cephalozia leucantha, Calypogeia sphagnicola, Calypogeia neesiana and Sphenolobus minutus [YSU-MH-00096]; 16: dwarf birch tundra, on clay spots, mixed with Anthelia juratzkana and Cephalozia bicuspidata [YSU-MH-00607].

LoPHOZIA SILVICOLA H.Buch (gem., ant., per.) - 1, 3, 13, 14, 18, 19 (Fr.): on soil, litter and decayed wood in river valley coniferous forests [KPABG(H):122269], in secondary mountain birch-green moss forests, in boggy peat-moss spruce open woodlands in pure mats [YSUMH-00207] but more often mixed with other bryophytes of such habitats: Lophoziopsis longidens, Fuscocephaloziopsis lunulifolia, Tritomaria exsectiformis, etc.

LOPHOZIA WENZELII (Nees) Steph. var. wenzelii (gem.) - 16: rocky dwarf shrub (Betula nana, Vaccinium uliginosum, $V$. vitis-idaea, Empetrum hermaphroditum, Diapensia lapponica) tundra between rocks, mixed with Gymnomitrion concinnatum and Sphenolobus minutus [YSUMH-00492].

LOPHOZIA MURMANICA Kaal. [Lophozia wenzelii var. groenlandica (Nees) Bakalin] (gem.) - 1, 9, 16, 17 (Sp.): in dwarf shrub and rocky dwarfshrub tundra, between rock, in pure mats or mixed with Trilophozia quinquedentata, Barbilophozia sudetica, Diplophyllum taxifolium [KPABG(H):122285], on bank of stream under snowfield, on fine earth mixed with Anthelia juratzkana, Fuscocephaloziopsis albescens and Diplophyllum taxifolium [KPABG(H):122287] in open woodlands and on organic litter on ledges of carbonate rocks in forest belt.

LOPHOZIOPSIS EXCISA (Dicks.) Konstant. et Vilnet (per., gem.) - 16: dwarf shrub tundra, in $D i-$ cranum fragilifolium turf mixed with Lophozia murmanica [YSU-MH-00519]; 17: bank of stream under snowfield, single shoots among mosses [YSU-MH-00540].

LOPHOZIOPSIS LONGIDENS (Lindb.) Konstant. et Vilnet (per., ant., gem.) - 1, 2, 13, 15, 17 (Sp.): in mixed birch-spruce forests in river valley and on slopes of mountains, at base of trunks and on decaying wood [KPABG $(\mathrm{H})$ : 122242], mixed with other liverworts characteristic for decaying wood (Lophozia guttulata, L. ascendens Tritomaria exsectiformis, etc.). It was once collected in dwarf-shrub-green moss tundra in turf dominated by Dicranum fragilifolium.

MARCHANTIA POLYMORPHA ssp. MONTIVAGANS Bischl. et Boissel.-Dub. - 12: floodplain forest, on bare soil; 22: dwarf willow-herb-green moss community on silty-gravel river bank [YSU-MH-00792].

Marchantia QUADRATA Scop. [Preissia quadrata (Scop.) Nees] (per., spor.) - 17: on fine earth on bank of stream under snowfield, mixed with bryophytes [KPABG(H):122286].

MARSUPElla SPRUCEI (Limpr.) Bernet (per., spor.) - 16 rocky dwarf shrub tundra on top of mountain, on clay spots, mixed with Solenostoma confertissimum, S. sphaerocarpum, Anthelia juratzkana and Prasanthus suecicus [YSU-MH-00503].

MEsoptYchia collaris (Nees) L. Söderstr. et Váňa [Leiocolea collaris (Nees) Schljakov] - 7, 9, 15, 17 (Sp.): on fine earth between rocks on rock outcrops on mountain slopes in forest belt, [YSU$\mathrm{MH}-00150]$, on peat on bank of lake, on banks of streams under snowfields in pure mats or mixed with other bryophytes, mostly calciphytes (Scapania gymnostomophila, Tritomaria scitula, Marchantia quadrata, etc.)

MEsoptychia Heterocolpos (Thed. ex Hartm.) L. Söderstr. et Váňa [Leiocolea heterocolpos (Thed. ex C. Hartm.) H. Buch] (gem., per.) - 5, 9, 17 (Sp.): on peat-moss hummocks and decayed stumps in moist Picea obovata-EquisetumSphagnum open woodlands [KPABG(H):122245] , on mountain slope between carbonate rocks in coniferous dwarf shrub-green moss forest, on fine earth on bank of stream under snowfield [YSU-MH-00584], usually mixed with other bryophytes.

** Mesoptychia RUtheana (Limpr.) L. Söderstr. et Váňa [Leiocolea rutheana (Limpr.) Müll. Frib.] 8: dwarf birch-sedge-moss rich fen at the base of carbonate rock [KPABG(H):122253], mixed with Scorpidium revolvens, S. scorpioides, Meesia 
triquetra and Campylium stellatum. The species was previously recorded in the Northern Urals (Zheleznova \& Shubina, 1998; Konstantinova \& Bezgodov, 2005). This is the first record of the species for Subpolar Urals.

** Metzgeria furcata (L.) Corda - 17: rock outcrops in dwarf birch tundra, in shaded niches between rocks, mixed with Isopterygiopsis pulchella, Cynodontium strumiferum, Trilophozia quinquedentata, Tritomaria scitula and Distichium capillaceum [KPABG(H):122291]. This is the northernmost locality in the Urals and the first record of the species in the Asian part of the Urals

Mylia ANOMALA (Hook.) Gray (gem.) - 4, 6, 14, 21 (Sp.): in boggy dwarf birch-peat-moss (Sphagnum fuscum) open spruce woodlands, in flat palsa mires usually mixed with Sphagnum [KPABG(H): 122293].

NARDiA GEOSCYPhus (De Not.) Lindb. - 17: bank of stream under snowfield, on fine earth, mixed with Plectocolea subelliptica [YSU-MH-00539].

Odontoschisma elongatum (Lindb.) A. Evans 3: palsa mire complex, waterlogged hollow in thermokarst depression [YSU-MH-00795, YSUMH-00796], in mossy Equisetum-Carex rostrata community, single shoots among Sphagnum centrale and Scorpidium revolvens.

Odontoschisma fluitans (Nees) L.Söderstr. \& Váňa [Cladopodiella fluitans (Nees) Jørg.] - 24: aapa mire, in Menyanthes trifoliata-sedge-moss hollows, some shoots mixed with Sphagnum centrale and S. platyphyllum [YSU-MH-00639], in waterlogged hollow with Trichophorum cespitosum and Drosera anglica, and on peat with Sphagnum subsecundum, Scapania paludicola and Straminergon stramineum.

Pellia NEEsiana (Gottsche) Limpr. (ant., per.) - 12: floodplain forest, on soil; 22: dwarf willow-herbgreen moss community on silty-gravel on bank of river, mixed with Ptychostomum pallens, Calliergon cordifolium and Calliergonella lindbergii [KPABG(H): 122236].

Plectocolea hyalina (Lyell) Mitt. [Solenostoma hyalinum (Lyell) Mitt.] - 18: gravelly flooded river bank, in pure mats [KPABG(H):122240]; 22: dwarf willow-herb-green moss community on silty-gravel bank, mixed with Scapania irrigua, Calliergonella lindbergii and Pohlia filum [KPABG(H):122238].
* Porella platyphylla (L.) Pfeiff. - 9, 10, 17 (Sp.): on shaded carbonate rocks in forest belt [KPABG(H):122256] or in niches on cliffs in dwarf birch tundra [YSU-MH-00138, 00591] usually in pure mats. The species is recorded for the first time for the Asian part of Subpolar Urals.

Prasanthus suecicus (Gottsche) Lindb. - 16: dwarf shrub tundra, on clay spots, two specimens with single shoots in mats with other arctic-montane liverworts: Marsupella sprucei, Anthelia juratzkana, Gymnomitrion spp., etc. [YSU-MH-00503, 504].

Protolophozia Elongata (Steph.) Schljakov (per.) 6: boggy Betula nana-Rubus chamaemorusSphagnum fuscum open spruce woodland at the base of slope, on peat, in mixed with Fuscocephaloziopsis leucantha, Cephalozia ambigua, Calypogeia sphagnicola, C. neesiana, Sphenolobus minutus [KPABG(H):122247] and in almost pure mat with some shoots of Cephalozia ambigua [YSU-MH-00097]. Red-listed in Russia (as Lophozia elongata Steph., Bardunov, 1998). This species was known previously in Urals from two findings in Vishera State Nature Reserve (Konstantinova \& Bezgodov, 2005) and one collection in the Upper Puiva River area (Konstantinova \& Lapshina, 2017).

Ptilidium CiliaRe (L.) Hampe - 3, 11, 14, 17, 19 (Sp.): in birch and birch-spruce mountain and river valley forests, on rock outcrops, and on litter and soil in forest floor; in swampy willow thickets [KPABG(H):122266], in low shrub (Salix spp., Betula nana)-sedge (Carex arctisibirica)peat moss mire in tundra belt.

PTILIDIUM PUlChERRIMUM (Weber) Vain. (per., spor.) - 1, 2, 3, 13 (Sp.): in birch-spruce and mixed (Pinus sibirica, Picea obovata, Betula pubescens) dwarf shrub-herb river valley forests at base of trees and on decayed wood, in pure mats and mixed with Sanionia uncinata, Lophoziopsis longidens, Lophocolea heterophylla and Dicranum fragilifolium $[\operatorname{KPABG}(\mathrm{H}): 122241]$

Radula complanata (L.) Dumort. (per., spor.) 11: huge boulder on gentle mountain slope, on rock [YSU-MH-00337], mixed with Neckera oligocarpa; 15: rock outcrops on mountainside in young birch forest, on shaded rocks, in pure mats or with mixed with Neckera oligocarpa, Pseudoleskeella rupestris, Zygodon sibiricus, Chionoloma tenuirostre and Frullania austinii [YSU-MH-00454]. 
RicCARDIA cf. CHAMEDRYFOlia (With.) Grolle - 21 central part of aapa mire, Menyanthes-sedge waterlogged hollow, single shoots on peat with Sarmentypnum exannulatum [YSU-MH-00647].

RicCARDIA LATIFRONS (Lindb.) Lindb. - 3: birchspruce river valley forest, on decayed wood, mixed with Lophoziopsis longidens and Fuscocephaloziopsis lunulifolia [YSU-MH-00084].

SACCOBASIS POLITA (Nees) H.Buch - 17: on bank of stream under snowfield on fine earth mixed with Lescuraea saxicola and Bartramia ithyphylla [KPABG(H):122280].

SCAPANIA CURTA (Mart.) Dumort. (per.) - 3: birchspruce river valley forest, on decayed wood, single shoots with Lophozia guttulata, Lophoziopsis longidens, Tritomaria exsectiformis, Lophozia ascendens and Fuscocephaloziopsis lunulifolia [KPABG(H):122244].

SCAPANia Cuspiduligera (Nees) Müll.Frib. (gem.) - 15: rock outcrops on steep mountain slope in young birch forest, on organic litter covered rocks, single shoots among Blepharostoma trichophyllum and Pohlia cruda [YSU-MH-00420].

Scapania gymnostomophila Kaal. (gem.) - 9, 10, 11 (Sp.): carbonate rocks in forest belt, in shaded niches between rocks, often in pure mats [KPABG(H):122248, KPABG(H):122254] or mixed with other calciphiles.

SCAPANIA IRRIGUA (Nees) Nees (gem.) - 1, 17, 21, 22 (Sp.): birch-willow-sedge-peat-moss mires, [YSU-MH-00228], in sedge (Carex lasiocarpa)peat-moss ridge in aapa mire, on silty-gravel soil in willow-grass-green moss community on river banks [KPABG(H):122237], on slope along stream bank under snowfield.

SCAPANiA MUCRONATA H. Buch - 1, 3, 11(Sp.): on decayed wood in birch-spruce river valley forest [YSU-MH-00089], in mixed Pinus sibirica-birchspruce river valley forest, [YSU-MH-00068], on fine earth covered ledge on boulder on gentle slope. Usually mixed with other bryophytes (Sanionia uncinata, Lophoziopsis longidens, Pohlia nutans, Fuscocephaloziopsis lunulifolia etc.).

SCAPANIA OBCORDATA (Berggr.) S. W. Arnell - 18: gravelly flooded river bank [KPABG(H):122239].

Scapania Paludicola Loeske et Müll.Frib. - 1, 17, 21, 24 (Sp.): in hollows and on hummocks in transitional fens, aapa mires, on stream banks under snowfield, in pure mats
[KPABG(H):122297] or mixed with Ptychostomum pseudotriquetrum, Polytrichum jensenii, Sanionia uncinata and Schljakovia kunzeana [KPABG(H):122252].

SCAPANIA PARVIFOLIA Warnst. - 16: dwarf birch tundra, on clay spots, single shoots mixed with Prasanthus suecicus, Gymnomitrion corallioides, G. concinnatum, Solenostoma sp., Sphenolobus minutus, Barbilophozia sudetica and Isopaches bicrenatus [YSU-MH-00504].

** (*) Scapania SPhaerifera H. Buch et Tuom. 11: large boulder on gentle mountain slope, on ledge of rock, on fine earth [KPABG(H):122121]. The species is extremely rare in Europe where it is recorded in the type locality in Murmansk Province and recently in Ural in Vishera State Nature Reserve (Konstantinova et al. 2019). However the species is not rare in Siberia including the mountains of South Siberia (1. c.) so its finding in the Asian part of the Urals is more or less predictable.

ScAPANia Subalpina (Nees ex Lindenb.) Dumort. - 1: bank of small stream, on silted fine earth [YSU-MH-00243]; 17: bank of stream under snowfield, on fine earth [KPABG(H):122281].

Scapania uliginosa (Sw. ex Lindenb.) Dumort. - 21: central part of aapa mire complex, Carex lasiocarpa-peat-moss hummock in small hollow [KPABG(H):122296].

ScAPANiA undulata (L.) Dumort. - 2: river bank, on flooded rocks, pure mats [YSU-MH-00646].

*** Schistochilopsis GRANDiREtis (Lindb. ex Kaal.) Konstant. - 14: Betula nana-Rubus chamaemorus-peat-moss open spruce woodland, mixed with Fuscocephaloziopsis pleniceps and Rhizomnium pseudopunctatum [KPABG(H):122261]; 15: rock outcrops on slope in young birch forest, on fine earth between rocks, single shoots mixed with Blepharostoma trichophyllum, Mesoptychia collaris and Pohlia cruda [YSU-MH-00419]; 17: on bank of stream under snowfield, single shoots among Blepharostoma trichophyllum Plectocolea cf. subelliptica, Trilophozia quinquedentata f. gracilis and Fuscocephaloziopsis pleniceps [YSU-MH-00587]. This arctomontane species is widespread in the north of the Holarctic but usually occurs in small populations and is probably overlooked.

SchlJAKOVIA KUNZEANA (Huebener) Konstant. et Vilnet (gem., per., spor.) - 1, 11, 14, 17, 23 (Fr.): 
in boggy dwarf birch-Rubus chamaemorus-peat moss open spruce woodlands, in swampy forests and willow thickets, on hummocks in transitional fens, in dwarf shrub-sedge- Sphagnum warnstorfii dominated bogs, sporadic in moist niches on carbonate rock outcrops, in pure mats [KPABG(H):122265 or mixed with other bryophytes.

SchlJAKOVIANTHUS QUADRILOBUS (Lindb.) Konstant. et Vilnet - 17: low dwarf shrub (Salix, Betula nana-Carex arctisibirica-peat-moss) mire in Sphagnum warnstorfii turf [KPABG(H):122275] and on bank of stream under snowfield, on fine earth, mixed with Scapania subalpina and $S$. paludicola [KPABG(H):122288].

Solenostoma confertissimum (Nees) Schljakov (per., spor.) - 16: dwarf shrub tundra on top of mountain, on bare spots, mixed with Marsupella sprucei, Anthelia juratzkana, Prasanthus suecicus and Solenostoma sphaerocarpum [YSUMH-00503]; 17: stream bank under snowfield [KPABG(H):122282].

SOLENOSTOMA SPHAEROCARPUM (Hook.) Steph. - 16: dwarf birch tundra, on clay spots, mixed with Solenostoma confertissimum [YSU-MH-00608]; and single shoots mixed with Solenostoma confertissimum, Marsupella sprucei, Anthelia juratzkana and Prasanthus suecicus [YSU-MH-00503]. Very small plants that fits well in description Solenostoma pusillum (C. E. O. Jensen) Steph. or Solenostoma sphaerocarpum var. nanum (Nees ex Flot.) R. M. Schust., both were recently synonymized with $S$. sphaerocarpum (Hodgetts et al., 2020).

Solenostoma subellipticum (Lindb. ex Heeg) R.M.Schust. [Plectocolea subelliptica (Lindb. ex Heeg) A. Evans] - 17: stream bank under snowfield, on fine earth, mixed with Nardia geoscyphus [YSU-MH-00539].

Sphenolobus minutus (Schreb.) Berggr. - 6, 9, 11, 16, 19 (Sp.): dwarf shrubs, dwarf birch rocky tundra, on clay spots and between rocks; in boggy dwarf shrub-peat moss open spruce woodlands; on carbonate rock outcrops in forests. Usually mixed with other bryophytes [KPABG(H):122247].

Sphenolobus saxicola (Schrad.) Steph. - 11: huge boulder on gentle mountain slope, on ledge of rock, in pure mats [KPABG(H):122257] and mixed with Tetralophozia setiformis [KPABG(H):122258].
TETRALOPHOZIA SETIFORMis (Ehrh.) Schljakov 11: Huge rock block on gentle mountain slope, on ledge of rock with Sphenolobus saxicola [KPABG $(\mathrm{H}): 122258]$; 16: rocky dwarf shrub tundra, on rocks [KPABG(H):122270].

TRILOPHOZIA QUINQUEDENTATA (Huds.) Bakalin [Tritomaria quinquedentata (Huds.) H.Buch] $-6,9,11,17$ (Fr.): in moist dwarf shrubs gravelly tundras, on litter on cliff ledges both in forests and mountain-tundra, in Betula nanaCarex arctisibirica-peat-moss mires, in boggy Betula nana-peat-moss open spruce forests, in pure mats or mixed with other bryophytes [KPABG(H):122271]. Once on bank of stream under snowfield the arctic form Trilophozia quinquedentata f. gracilis was collected mixed with Anthelia juratzkana, Cephalozia bicuspidata and Fuscocephaloziopsis pleniceps [YSU-MH-00586].

TRITOMARIA EXSECTIFORMIS (Breidl.) Loeske (gem., ant.) - 3, 19: on decayed wood in birch-spruce and Pinus sibirica-birch-spruce river valley forests, usually mixed with other species of decaying wood (Lophozia ascendens, L. guttulata, Lophoziopsis longidens, etc. [YSU-MH-00074; YSU-MH-00068]; 19: birch-larch-Pinus sibirica dwarf shrub-peat moss community in high palsa complex, on decayed wood mixed with Lophozia silvicola and Sphenolobus minutus [YSU-MH-00207].

TRITOMARIA SCITULA (Taylor) Jørg. - 9: on organic litter on ledges of carbonate rocks, mixed with Trilophozia quinquedentata and Barbilophozia barbata [YSU-MH-00141] and on slope between carbonate rocks in Pinus sibirica-larch-spruce shrub-green-moss forest mixed with Mesoptychia heterocolpos, Scapania gymnostomophila and Arnellia fennica [KPABG(H):122249]; 17: rock outcrops in dwarf birch tundra, in shaded niches between rocks, single shoots among Metzgeria furcata, Isopterygiopsis pulchella, Distichium capillaceum and Trilophozia quinquedentata [YSU-MH-00606].

\section{DISCUSSION}

The liverwort flora of the Khulga River basin counts 84 species including seven (Arnellia fennica, Frullania austinii, Mesoptychia rutheana, Metzgeria furcata, Porella platyphylla, Scapania sphaerifera and Schistochilopsis grandiretis) new for the Khanty-Mansi Autonomous Area. Of these, Scapania sphaerifera was not previ- 
ously known for the Urals and was only recently discovered almost simultaneously on both the European and Asian parts of these mountains (Konstantinova et al., 2019). Locations in the Urals are almost 1,500 kilometers away from the only known location of the species in Europe and 1,800 kilometers and more from the Asian locations of the species. (1.c.) Frullania austinii is a recently described species which is not rare in Eurasia but found generally in more southern areas (Mamontov et al., 2020). The record from the Khulga River Basin is one of the northernmost known at present. The rest of the liverworts firstly recorded for the Autonomous Area are mainly mountain species more or less widespread in the North of Holarctic. Since most of the studied region's territory is swampy lowlands, there are very few suitable habitats for these species here.

A total of 144 species incl. 2 subspecies and one variety have been recorded in three territories studied on the Asian slopes of the Urals within the Khanty-Mansi Autonomous Area. Of these 55 species or ca. $37 \%$ are represented in all three studied areas. All liverworts common for three studied areas are widespread in the north of Holarctic and they are mostly the most common species in the studied areas (Appendix). The diversity of liverworts in the Khulga River basin is slightly less than in the previously studied flora of Ner-Oika mountain (97 species) or the Upper Puiva River basin (104 species), located $120 \mathrm{~km}$ further south (Konstantinova \& Lapshina, 2014, 2017). This is mainly due to the fact that the Khulga river flows through low mountains and plains: most collecting sites were located here at altitudes not exceeding 100 meters and only three were located at altitudes of ca. 500-600 $\mathrm{m}$. The studied areas of the Ner-Oika Mt. (325$960 \mathrm{~m}$ alt.) and Puiva River basin (680-1030 $\mathrm{m}$ alt.) are located significantly higher. Of 17 liverworts specific to the Khulga River basin eleven are primarily or exclusively peat mires and swampy area species (Aneura pinguis, Riccardia chamedryfolia, Fuscocephaloziopsis connivens, $F$. leucantha, Odontoschisma fluitans, Cephaloziella hampeana, Mesoptychia rutheana, Heterogemma laxa, Scapania uliginosa and Schistochilopsis grandiretis). This is due to the much wider distribution and diversity of mires ecosystems in the Khulga River basin compared to other studied areas on the Eastern slopes of the Urals. Three species (Metzgeria furcata, Radula complanata and Porella platyphylla) are not rare in the Eurasia mainly mountain species, but more common in southern areas. For these species there are rather few appropriate habitats at high altitudes explored in Ner-Oika Mt. and Puiva River basin. Lophozia guttulata is a not rare species of coniferous forests that were not quite carefully studied in mentioned above areas because collecting there was mostly done in the upper belts. Arnellia fennica is a rather rare and scattered occurring species everywhere and Scapania sphaerifera is a rare species just recently found in Urals.

Twenty species known from both high mountain areas (Ner-Oika Mt. and Upper Puiva River Basin) have not been found in the Khulga River basin. These are mostly not rare arctomontane species of rocky areas in subalpine and tundra zones (Diplophyllum albicans, D. obtusifolium, Neoorthocaulis floerkei, N. binsteadii and Saccobasis polymorpha) or mountain species characteristic of rocky banks and beds of mountain cricks (Scapania paludosa and Plectocolea obovata) or species of bare soil (Cephaloziella varians, Nardia japonica and Solenostoma caespiticium).

Significant differences in the composition of the floras of the compared areas can be explained by differences not only in geology and geomorphology described above but as well by relatively the small size of territories and representation by a small numbers of collections in each type of habitat.

Among the species of phytogeographic interest in addition to Scapania sphaerifera discussed above should be noted Protolophozia elongata. It is a rather rare worldwide species red-listed in Russia (Bardunov, 2008). In the Urals the species is recorded in the western slope of the Northern Urals in the Vishera State Nature reserve (Konstantinova, Bezgodov, 2005; Ignatova et al., 2019) and in one locality in Asian slopes of Urals (Konstantinova, Lapshina, 2017).

In general the liverwort flora of the Khulga river Basin is not very diverse and original. But the data obtained significantly expand our understanding of both the flora of the Subpolar Urals and the distribution and ecology of species in the Urals. 


\section{ACKNOWLEDGMENTS}

We are grateful to A. Hagborg for valuable comments and correction of English. A. Savchenko is kindly thanked for preparing the map of the studied area. The research of Lapshina and Filippov was partially supported by RFBR and Government of the Khanty-Mansi Autonomous Area - Yugra, project 18-44-860017, the study of Konstantinova was partly supported by RFBR, project 18-04-00594.

\section{REFERENCES}

Baisheva, E. Z. \& Potemkin A. D. 1998. On the liverwort flora of Bashkiria. Bot. Zhurn. 83 (9): 46-52. 22. (In Russian)

Bakalin, V. A., Konstantinova N. A. \& Zheleznova, G. V. 2001. On the liverwort flora of Northern Urals (Komi Republic). In: Botanicheskie issledovaniya na ohranyaemyh territoriyah evropejskogo severovostoka. Trudy Komi nauchnogo centra UrO RAN, 165: 208-216.

Bardunov, L. V. (ed.) 2008. Red Data Book of the Russian Federation (plants and fungi). Moscow, Ministerstvo prirodnykh resursov i ekologii Rossijskoj Federatsii. Pp. 599-662. (In Russian)

Dulin, M. V. 2007. Liverworts of the Middle Taiga Subzone of the Russian European North-East. Ekaterinburg. 195 pp. (In Russian)

Hodgetts, N. G., Söderström, L., Blockeel, T. L., Caspari, S., Ignatov, M. S., Konstantinova, N. A., Lockhart, N., Papp, B., Schröck, C., Sim-Sim, M., Bell, D., Bell, N. E., Blom, H. H., BruggemanNannenga, M. A., Brugués, M. J., Enroth, K. I. Flatberg, Garilleti, R., Hedenäs, L., Holyoak, D. T., Hugonnot, V. Kariyawasam, I., Köckinger, H., Kučera, J., Lara, F. \& Porley, R. D. 2020. An annotated checklist of bryophytes of Europe, Macaronesia and Cyprus. J. of Bryology 42(1): 1-116. https://doi.org/10.1080/03736687.20 19.1694329

Ignatova, E. A., Ignatov, M.S ., Konstantinova, N. A. \& Bezgodov, A., G. 2019. Bryophytes of Vishera State Nature Reserve. 122 pp. (In Russian).

Konstantinova, N. A. \& Bezgodov, A. G. 2005. Hepatics of Vishera State Nature Reserve (Perm' Province, Northern Ural Mountains). Arctoa 14: 163-176 (in Russian with English summary). https://doi. org/10.15298/arctoa. 14.12
Konstantinova, N. A., Bezgodov, A. G. \& Savchenko A. N. 2010. Hepatics of Basegi State Nature Reserve (Perm province). Novosti Sist. Nizsh. Rast. 44: 322-336. (In Russian with English abstract).

Konstantinova, N. A. \& Chernyadjeva, I. V. 1995. Hepatics of the middle course of Sob' River (Polar Ural). Novosti Sist. Nizsh. Rast. 30: 110-121. (In Russian with English abstract)

Konstantinova, N. A. \& Lapshina, E. D. 2014. On the Hepatic flora of the Eastern Subpolar Ural (Khanty-Mansi Autonomous District. Arctoa 23: 80-90. https://doi.org/10.15298/arctoa.23.09

Konstantinova, N. A. \& Lapshina, E. D. 2017. The hepatics of the Puiva River (Sub-Polar Ural, Khanty-Mansi Autonomous District). Arctoa 26: 35-46. https://doi.org/10.15298/arctoa.26.03

Konstantinova, N. A., Vilnet, A. A. \& Lapshina, E. D. 2019. New finding of Scapania sphaerifera H. Buch et Tuom. in Europe with description of global distribution and ecology of the species. Arctoa 28: 203-209. https://doi.org/10.15298/ arctoa. 28.17

Lapshina, E. D., Ignatova, E. A., Ignatov, M. S., Ganasevich, G. N. \& Skuchas, Yu. V. 2020. The mosses of the Khulga River Basin (Subpolar Urals, Khanty-Mansi Autonomous Area-Yugra). Novosti Sist. Nizsh. Rast. 54(1): 211-241. https://doi. org/10.31111/nsnr/2020.54.1.211.

Lapshina, E. D., Filippov, I. V. \& Verevkina, E. L. 2018. A contribution to the moss and hepatic flora of Nature Park "Numto" (Khanty-Mansi Autonomous District, Western Siberia). Environmental Dynamics and Global Climate Change. V. 9. No 1. Pp. 3-21. (In Russian with English abstract). https: / / doi.org/10.17816/edgcc8930

Mamontov, Yu. S., Vilnet, A. A., Atwood, J. J. \& Konstantinova N. A. 2020. Molecular phylogenetic study of Frullania subsect. Inflatae (Frullaniaceae, Marchantiophyta) in the Holarctic with description of a new subgenus and three new species. Nova Hedwigia 150:. 201-242. https:// doi.org/10.1127/nova-suppl/2020/201

Zheleznova, G. V. \& Shubina, T. P 1998. Bryophytes of Pechora-Ilych Reserve. Flora ifauna zapovednikov 65. Moscow. 34 pp. (In Russian).

Zinov'eva, L. A. 1973. To the hepatic flora of the Polar and Northern Urals. Uchoenye Zapiski Permskogo Gosudarstvennogo Universiteta, Botanika, 263: 14-37. (In Russian). 
Appendix. List of liverworts of the Asian part of the Subpolar Urals

Taxon

Number of collected specimens in studied areas

Surroundings of Upper Puiva Khulga the Ner-Oika Mt. River Basin River Basin

Aneura pinguis (L.) Dumort.

Anthelia juratzkana (Limpr.) Trevis.

Arnellia fennica (Gottsche) Lindb.

Asterella lindenbergiana (Corda ex Nees) Lindb. ex Arnell

Barbilophozia barbata (Schmidel ex Schreb.) Loeske

Barbilophozia hatcheri (A.Evans) Loeske

Barbilophozia lycopodioides (Wallr.) Loeske

Barbilophozia sudetica (Nees ex Huebener) L.Söderstr., De Roo \& Hedd.

[Pseudolophozia sudetica (Nees ex Huebener) Konstant. \& Vilnet]

Biantheridion undulifolium (Nees) Konstant. \& Vilnet

Blasia pusilla L.

Blepharostoma trichophyllum (L.) Dumort. subsp. brevirete (Bryhn \& Kaal.) R.M.Schust.

Blepharostoma trichophyllum (L.) Dumort. var. trichophyllum

Calycularia laxa Lindb. \& Arnell

Calypogeia integristipula Steph.

Calypogeia muelleriana (Schiffn.) Müll.Frib.

Calypogeia neesiana (C.Massal. \& Carestia) Müll.Frib.

Calypogeia sphagnicola (Arnell \& J.Perss.) Warnst. \& Loeske

Cephalozia ambigua C.Massal.

Cephalozia bicuspidata (L.) Dumort.

Cephaloziella arctogena (R.M.Schust.) Konstant.

Cephaloziella divaricata (Sm.) Schiffn.

Cephaloziella grimsulana (J.B.Jack ex Gottsche \& Rabenh.) Lacout.

Cephaloziella hampeana (Nees) Schiffn. ex Loeske

Cephaloziella rubella (Nees) Warnst.

Cephaloziella spinigera (Lindb.) Jørg.

Cephaloziella varians (Gottsche) Steph.

Chiloscyphus pallescens (Ehrh.) Dumort.

Chiloscyphus polyanthos (L.) Corda

Clevea hyalina (Sommerf.) Lindb. [Athalamia hyalina (Sommerf.) S.Hatt.

Conocephalum conicum (L.) Dumort.

Diplophyllum albicans (L.) Dumort.

Diplophyllum obtusifolium (Hook.) Dumort.

Diplophyllum taxifolium (Wahlenb.) Dumort.

Endogemma caespiticia (Lindenb.) Konstant., Vilnet \& A.V.Troitsky

Frullania austinii J. J. Atwood, Vilnet, Mamontov et Konstant.

Fuscocephaloziopsis (Hook.) Váňa \& L.Söderstr.

Fuscocephaloziopsis connivens (Dicks.) Váňa \& L.Söderstr.

Fuscocephaloziopsis leucantha (Spruce) Váňa \& L.Söderstr.

Fuscocephaloziopsis lunulifolia (Dumort.) Váňa \& L.Söderstr.

Fuscocephaloziopsis lunulifolia (Dumort.) Váňa \& L.Söderstr.

Gymnocolea inflata (Huds.) Dumort.

Gymnomitrion brevissimum (Dumort.) Warnst.

Gymnomitrion concinnatum (Lightf.) Corda

Gymnomitrion corallioides Nees

Harpanthus flotovianus (Nees) Nees

Heterogemma laxa (Lindb.) Konstant. \& Vilnet

Hygrobiella laxifolia (Hook.) Spruce
16

$\cdot$

2

9

9

33

2

7

.

10

.

2

2

.

2

7

38

7

3

3

.

.

2

4

3

2

.

12

2

2

2

2

$$
\begin{aligned}
& 9 \\
& 5
\end{aligned}
$$$$
24
$$$$
17
$$$$
14
$$

\section{1}

3

13

6

5

3

$$
\text { . }
$$

$$
4
$$

$$
3
$$$$
3
$$

14

$$
1
$$$$
3
$$$$
1
$$$$
\text { . }
$$$$
3
$$$$
3
$$

$$
\begin{aligned}
& 1 \\
& 9
\end{aligned}
$$

\section{6}

\section{6}

$$
1
$$

$$
7
$$

.$$
\text { . }
$$

\section{8}

4

$$
9
$$$$
4
$$ 
Isopaches bicrenatus (Schmidel ex Hoffm.) H.Buch

Jungermannia atrovirens Dumort.

Jungermannia borealis Damsh. \& Váňa

Jungermannia eucordifolia Schljakov [Jungermannia exsertifolia subsp. cordifolia (Dumort.) Vána]

Jungermannia polaris Lindb.

Jungermannia pumila With.

Lepidozia reptans (L.) Dumort.

Lophocolea heterophylla (Schrad.) Dumort.

Lophocolea minor Nees

Lophozia ascendens (Warnst.) R.M.Schust.

Lophozia guttulata (Lindb. \& Arnell) A.Evans

Lophozia longiflora (Nees) Schiffn.

Lophozia murmanica Kaal.

Lophozia silvicola H.Buch

Lophozia ventricosa (Dicks.) Dumort.

Lophozia wenzelii (Nees) Steph.

Lophozia wenzelii (Nees) Steph. var. massularioides Bakalin

Lophoziopsis excisa (Dicks.) Konstant. \& Vilnet

Lophoziopsis jurensis (Meyl. ex Müll.Frib.) Mamontov \& Vilnet [Lophozia propagulifera auct. eur.]

Lophoziopsis longidens (Lindb.) Konstant. \& Vilnet

Lophoziopsis pellucida (R.M.Schust.) Konstant. \& Vilnet

Lophoziopsis polaris (R.M.Schust.) Konstant. \& Vilnet

Marchantia polymorpha L. ssp. montivagans Bischl. \& Boissel.-Dub.

Marchantia quadrata Scop. [Preissia quadrata (Scop.) Nees]

Marsupella apiculata Schiffn.

Marsupella boeckii (Austin) Lindb. ex Kaal.

Marsupella condensata (Ångstr. ex C.Hartm.) Lindb. ex Kaal.

Marsupella emarginata (Ehrh.) Dumort.

Marsupella sprucei (Limpr.) Bernet

Mesiptychia gillmanii (Austin) L.Söderstr. \& Váňa

Mesoptychia badensis (Gottsche ex Rabenh.) L.Söderstr. \& Váňa

Mesoptychia bantriensis (Hook.) L.Söderstr. \& Váňa

Mesoptychia collaris (Nees) L.Söderstr. \& Váňa

Mesoptychia heterocolpos (Thed. ex Hartm.) L.Söderstr. \& Váňa

Mesoptychia rutheana (Limpr.) L.Söderstr. \& Váňa

Metzgeria furcata (L.) Corda

Mylia anomala (Hook.) Gray

Nardia breidleri (Limpr.) Lindb.

Nardia geoscyphus (De Not.) Lindb.

Nardia japonica Steph.

Neoorthocaulis binsteadii (Kaal.) L.Söderstr., De Roo \& Hedd. [Orthocaulis binsteadii (Kaal.) H.Buch]

Neoorthocaulis floerkei (F.Weber \& D.Mohr) Loeske [Orthocaulis floerkei (F.Weber \& D.Mohr) H.Buch]

Obtusifolium obtusum (Lindb.) S.W.Arnell

Odontoschisma elongatum (Lindb.) A.Evans

Odontoschisma fluitans (Nees) L.Söderstr. \& Váňa [Cladopodiella fluitans (Nees) H.Buch]

Odontoschisma macounii (Austin) Underw.

Odontoshisma francisci (Hook.) L.Söderstr. \& Váňa [Cladopodiella francisci (Hook.) Jørg.]

Pellia neesiana (Gottsche) Limpr. 
Porella platyphylla (L.) Pfeiff.

Prasanthus suecicus (Gottsche) Lindb.

Protolophozia elongata (Steph.) Schljakov

Ptilidium ciliare (L.) Hampe

Ptilidium pulcherrimum (Weber) Vain.

Radula complanata (L.) Dumort.

Riccardia chamedryfolia (With.) Grolle

Riccardia latifrons (Lindb.) Lindb.

Saccobasis polita (Nees) H.Buch

Saccobasis polymorpha (R.M.Schust.) Schljakov

Sauteria alpina (Nees) Nees

Scapania crassiretis Bryhn

Scapania curta (Mart.) Dumort.

Scapania cuspiduligera (Nees) Müll.Frib.

Scapania degenii Schiffn. ex Müll.Frib.

Scapania gymnostomophila Kaal.

Scapania hyperborea Jørg.

Scapania irrigua Nees

Scapania irrigua Nees subsp. rufescens (Loeske) R.M.Schust. (as var. rufescens)

Scapania kaurinii Ryan

Scapania mucronata H.Buch

Scapania obcordata (Berggr.) S.W.Arnell

Scapania paludicola Loeske \& Müll.Frib.

Scapania paludosa (Müll.Frib.) Müll.Frib.

Scapania parvifolia Warnst.

Scapania praetervisa Meyl.

Scapania scandica (Arnell \& H.Buch) Macvicar

Scapania sphaerifera H.Buch \& Tuom.

Scapania spitsbergensis (Lindb.) Müll.Frib.

Scapania subalpina (Nees ex Lindenb.) Dumort.

Scapania tundrae (Arnell) H.Buch

Scapania uliginosa (Lindenb.) Dumort.

Scapania undulata (L.) Dumort.

Schistochilopsis grandiretis (Lindb. ex Kaal.) Konstant.

Schistochilopsis incisa (Schrad.) Konstant.

Schistochilopsis opacifolia (Culm. ex Meyl.) Konstant.

Schljakovia kunzeana (Huebener) Konstant. \& Vilnet

Schljakovianthus quadrilobus (Lindb.) Konstant. \& Vilnet

Solenostoma confertissimum (Nees) Schljakov

Solenostoma hyalinum (Lyell) Mitt. [Plectocolea hyalina (Lyell) Mitt.]

Solenostoma sphaerocarpum (Hook.) Steph. [Solenostoma pusillum (C.E.O.Jens.) Steph., Solenostoma sphaerocarpum var. nanum (Nees ex Flot.) R.M.Schust.]

Solenostoma subellipticum (Lindb. ex Heeg) R.M.Schust. [Plectocolea subelliptica (Lindb. ex Kaal.) A.Evans]

Sphenolobus minutus (Schreb. ex D.Crantz) Berggr.

Sphenolobus saxicola (Schrad.) Steph.

Tetralophozia setiformis (Ehrh.) Schljakov

Trilophozia quinquedentata (Huds.) Bakalin

$$
\text { . }
$$

.

10

-

